\title{
Snapshot of a Life Reassessed: Edith Searle Grossmann
}

\section{Rebecca Burns}

In 2007, in a special edition of Kōtare: New Zealand Notes \& Queries, Kirstine Moffat offered a biographical sketch of the feminist and author, Edith Searle Grossmann (1863-1931). ${ }^{1}$ Moffat described Grossmann in her online article as writing 'the two most significant New Zealand novels to come out of the nineteenth-century women's movement', and remarked that Grossmann's In Revolt (1893) and A Knight of the Holy Ghost (1907, republished as Hermione: A Knight of the Holy Ghost in 1908) offered 'powerful critiques of [the] gender inequities' existing in New Zealand before the First World War. These texts were, Moffat writes, the work of '[a]n independent career woman' and that 'in her life as well as her art Grossmann upheld feminist ideals.' However, even though Grossmann was central to many feminist movements and organisations, such as being a founder member of the Christchurch Women's Institute in 1892 and the London Lyceum Club in 1905, little is known about her life other than the brief reviews provided by Moffat, Heather Roberts in the Dictionary of New Zealand Biography (updated 2007), Aorewa McLeod's essay in The Book of New Zealand Women (1991) and Jane Stafford's and Mark Williams' chapter about her work in Maoriland: New Zealand Literature 1872-1914 (2006). Controversy, therefore, remains about certain biographical issues. For example, Edith's husband, Joseph Penfound Grossmann (1864-1953) alleged that she was mentally ill - an assertion challenged by Moffat and McLeod, both of whom believe that Joseph initiated this myth in a desperate attempt to defend himself against charges of criminal activity. In addition, little is known about the relationship Grossmann had with her son, Arthur (born 1894), her family background, her appearance or her education. Now, following the acquisition of papers in 2007 by the Alexander Turnbull Library in Wellington, light can be shed upon these matters and the accepted perception of Grossmann's life can be reviewed. 
The documents belonged to Phoebe Churchill Meikle (1910-1997), a writer, editor and teacher from Auckland's North Shore, and were compiled in the 1950s from letters and interview notes with Grossmann's friends and relatives. $^{2}$ These were collected with a view to Meikle writing Grossmann's biography, which did not materialise, and they are invaluable to those interested in Grossmann's life. Of course, the contents of these documents should not be viewed as unmitigated fact - rather, they are recollections and opinions of Grossmann's friends obfuscated by the distance of time and the hidden agenda of the correspondent. However, the Meikle papers contain information that clarifies and expands upon the brief biographical sketches offered in Kōtare and elsewhere. Similarly, private documents belonging to Searle family descendents, viewed by this researcher and retained by the family, also enhance the understanding we have of Grossmann's life and background. Finally, contemporary newspaper articles, accessed through the National Library's Papers Past online database, yield extra clues about Grossmann's life and political interests, particularly in relation to her years in Europe (1903-1912). Drawing on these sources, this essay reassesses Edith Searle Grossmann's mental health, personal relationships, family background and education.

The Meikle papers, supplemented by private Searle family documents and historical records in the public domain (such as Birth, Marriages and Death records), contain information that augments the fundamental details of Grossmann's biography: in particular, the Meikle papers suggest that Grossmann's parents came from privileged backgrounds and reveal the previously unknown source of her middle name. In the Dictionary of New Zealand Biography, Heather Roberts informs us that Edith Howitt Searle was born on 8 September 1863 in Beechworth, Victoria, Australia. Her father was George Smales Searle, who was born on 27 Jan. 1823 (International Genealogical Index, online) and died on 16 June $1885^{3}$, and her mother was Mary Ann Beeby (20 June 1823-14 Nov. 1911). ${ }^{4}$ Further background information about the Searle and Beeby families is contained in the Meikle papers: Grossmann's nephew, Stanley G Frame (son of Edith's sister 
Constance), wrote that, in England, the families had been relatively affluent. They were

country folk whose estates bordered on each others [sic] properties at Saffron Walden in Essex, they used to be very friendly and visited each other frequently. Dancing, fox hunting, [h]orse [r]iding etc. Apparently they were not wealthy but very comfortable[,] having servants, maids and men to do their work on their estates (Frame, "Biographical Notes")

Further, the 1911 obituary of Edith's mother, published in an unidentified newspaper (a copy of which is retained by a Searle family descendent), records that her husband's family had been 'owners of a private bank' ('An Interesting Personality'). A brief biographical sketch of George Smales Searle, also held privately by a Searle descendant, notes that he became a 'wine and spirit merchant' (In Memoriam, 1) in Australia before becoming a newspaper editor. He married Mary Ann Beeby in South Yarra in 1854 (Births in the District of Beechworth, online), and the Registry of Births, Deaths and Marriages for Victoria (online) records that the Searle's first child, Alice Mary, was born in 1856, followed by George Arthur in 1858 (d. 1868), Laura in 1860 (d. 1909?), Edith Howitt in 1863 (d. 1931), and Constance Clive ${ }^{5}$ in 1865 (d. 1947). Edith's was the 258th recorded birth in the Beechworth district (Births in the District of Beechworth) and the Meikle papers reveal the source of her unusual middle name. At the time of her birth, George and Mary Searle were acquaintances of Dr. William Howitt (1792-1879), father of the explorer, Alfred William Howitt (1830-1908) ('An Interesting Personality'). In 1861, Howitt Jnr. famously led a search party tracking the location of an earlier group of explorers, led by Robert O'Hara Burke (1821-1861), who had also lived in Beechworth at the same time as the Searles, and who had set out to cross Australia from south to north. Burke's disastrous undertaking and his death (along with almost all of his party) has become one of Australia's foundational legends. Almost precisely two years after Alfred Howitt rescued the one surviving member of the Burke expedition in September, 1861, Edith Howitt Searle was born and named after the now celebrated rescuer. This is confirmed by Stanley Frame, who advised Phoebe Meikle that 
The Searles and Howitt the Australian explorer used to frequently visit each other and Edith Searle was named Edith Howitt Searle after them. I remember my mother telling me about it (Frame to Meikle, 25 May 1956).

It seems apt that Edith, who travelled extensively in Europe between 1903 and 1912, and who once commented that when she was young 'she used to sit and watch the boats passing and long to be in one' (Miller to Meikle, 6 Nov. 1955), would be named after a fellow traveller. Similarly, it is appropriate that a feminist, who challenged and questioned the role and position of women in the nineteenth century, should be named after a famous adventurer, who also pushed at the boundaries of human existence and knowledge in an unexplored colonial land.

The letters in the Meikle collection also provide a physical description of Edith Searle Grossmann, useful in that it is not found elsewhere and because her dishevelled appearance in later life was seen as indicative of a degenerative mental illness. Georgie Mackay, sister to both the poet Jessie Mackay (1864-1938) and Ness who kept house for Grossmann and nursed her during her last illness, thought that as a girl, Edith 'must have been quite beautiful - her hair was soft and copperbronze [sic] in colour, and she had noticeably protruding teeth (maybe she sucked her thumb as a baby!!) [sic]' (Mackay to Meikle, 31 Jan. 1956). Demonstrating the contradictory nature of reminiscence, another friend, Chrissie Gray, disagreed, remarking that Grossmann was '[n]o beauty', but 'she had gold hair, Roman nose, green eyes' and a 'lovely expression' (Interview with Gray, 5 Nov. 1955). However, in later life, many acquaintances agreed about Edith's untidy dress: an exstudent of her husband recalled that she was a 'dreamy vague sort of person' who, by 1898, when Joseph was imprisoned for fraud, seemed 'indifferent as to her appearance and dressed plainly and badly' (C. T. Hand Newton to Meikle, 13 Feb 1956). Her hair was by now 'lack-lustre[,] seldom adequately brushed or set' (C. T. Hand Newton to Meikle, 13 Feb 1956). Her friends thought her 'peculiar' method of dress related to a mental instability and the 'delusions' from which she apparently suffered (Unnamed Correspondent to Meikle, 6 Nov. 1955). 
In 1878 George Searle was employed by James Walker Bain, the proprietor of the Southland Times, to edit the paper, and the Searle family travelled across the Tasman Sea and settled in Invercargill (In Memoriam, 2). ${ }^{6}$ There, Edith attended Invercargill Grammar School, moving to Christchurch Girls' High School in 1879, where she was admission number 154 (Private Correspondence with School). Although she was not the Head Girl of the School as had been thought (Private Correspondence with School), she did become Dux in 1880 and 1881, gaining the best aggregate score in all subjects. Importantly, the Meikle papers disclose, for the first time, an incident that may have motivated Grossmann in her studies: her nephew, Stanley Frame, writes that as a youngster, she had

[...]a 'come day go day' style and attitude towards life until her mother[,] being determined to teach her a lesson, sent her out to domestic service in the employment of a clergyman (English) and apparently she had to wait on him, his wife and pampered children for long hours, seven days a week for a mere pittance as wages. This was the turning point in her young life and after returning home she started to study of her own accord being determined not to enter the 'domestic service' again (Frame, 'Biographical Notes').

Grossmann's determination was rewarded when she met Helen Connon, a teacher at Christchurch Girls' High School who became Principal in 1882. As Cherry Hankin notes in the Dictionary of New Zealand Biography, Connon had almost completed her BA when she met Edith, going on to attain her MA with honours in 1881, the first woman in the British Empire to do so (2007). She exerted considerable influence over Edith and other girls and, inspired by Connon, Edith attended Canterbury College, where she worked towards a BA. She achieved this in 1884 and an MA followed in 1885. Phoebe Meikle also noted, possibly erroneously, that Grossmann received the literary Bowen Prize for her essay in 1881 (Chronology of life of Edith Grossmann) ${ }^{7}$, and a search of contemporary newspapers reveals that she was runner-up in the same competition in 1882. This latter entry, the Otago Witness noted, was judged to be 'so close in point of excellence' (11 March 1882) to the winner 
that it was recommended Grossmann receive a certificate anyway, suggesting the continued high calibre of her work.

Whilst at Canterbury University College, Edith met her future husband. Joseph Penfound Grossmann was, by Georgie Mackay's account, a ‘young, brilliant, fascinating and handsome student' (Mackay to Meikle, 31 Jan. 1956). Born in Australia and the son of a 'Polish Jewish immigrant and English mother' (Blyth 11), Joseph Grossmann won a Junior Scholarship to Canterbury College in 1879 and graduated with an MA with triple honours in 1884, the first student in New Zealand to do so (Blyth 11). He began lecturing in Political Economy at Canterbury College in 1896 but, unable to manage money, was imprisoned for defrauding colleagues in 1898. His friends and colleagues, writing to Phoebe Meikle, suggest that his careless attitude towards money was a characteristic trait: an ex-student of his and Edith's housekeeper both recalled how he had borrowed money without paying it back (C. T. Hand Newton, 13 Feb. 1956; Blumhardt to Meikle, undated). Perhaps exercising caution, Edith did not marry Joseph upon graduation in 1885; instead she travelled north to Wellington, teaching at the newly established Girls' High School. An ex-pupil told Chrissie Gray that she found Edith to be a 'most inspiring teacher' who would 'stand in front of class, shut her eyes and by her words transport [the] girls to another world' (Interview with Gray, 5 Nov. 1955). Evidently, female access to education, then, was important to Edith. It was a key theme in her second novel, In Revolt, in which she depicted the psychological disintegration of Hermione Carlisle, a young, vibrant woman denied an education and trapped within an abusive marriage. Hermione's rallying cry — 'why shouldn't girls go to Universities too?' (42) powerfully vocalised a major preoccupation of the author.

The Meikle papers offer an important alternative view of the Grossmanns' marriage, complicating the commonly held belief that theirs was a disastrous relationship. However, when Edith and Joseph did marry on 23 December 1890, theirs did appear to have been an infelicitous, awkward match. Comments made to Phoebe Meikle reveal the fragile beginnings of their relationship: in a remark she asked Meikle to keep confidential, Georgie Mackay alleged that Joseph had originally been in love with Constance 
Searle. When Constance rejected him, Mackay asserts, Joseph turned his affections to Edith, her older sister (Mackay to Meikle, 31 Jan. 1956) although this is not supported elsewhere. The novelist Alan Mulgan (18811962) and his wife Marguerita, friends of the Grossmanns in Auckland, believed that Joseph married Edith 'partly out of pity [for] a lone, lonely woman' (Interview with Mulgan, 17 Jan. 1956) and partly because he was attracted by her intellect. Given this inauspicious start to their relationship, it is unsurprising that some critics, such as Kirstine Moffat in Kōtare, assert that the Grossmanns' marriage 'became increasingly unhappy' (2007) within only a few years. However, this is not the only view of the Grossmanns' relationship: some of Edith's friends spoke of Joseph's pride in his wife's 'brilliant' university career (Unnamed Correspondent to Meikle, 6 Nov. 1955) and others noted that he 'never lost his admiration for her former brilliant brain' (Mackay to Meikle, 31 Jan. 1956) despite Edith's apparent gradual mental deterioration. More emphatically, Chrissie Gray stated in an interview with Meikle that she could not 'sufficiently stress the fact that he [Joseph] adored her' even though he was alleged to have had affairs (Interview with Gray, 5 Nov. 1955). ${ }^{8}$ Thus letters written to Phoebe Meikle suggest that, whilst the couple did live apart from 1903 onwards when Edith travelled to London with her son, their ties were not severed irrevocably. On the contrary: a letter written by Miss Elle Blumhardt, Edith's housekeeper in Takapuna in 1916, reveals that, whilst their contact may have been rather stiff and formal, Joseph continued to support Edith financially, even when they lived apart (Blumhardt to Meikle, undated). Money was sufficient, though, only for the writer to live frugally on thin soups and sour porridge (Blumhardt to Meikle, undated).

On 5 December 1894 Edith gave birth to her only child, Arthur Searle, at New Brighton in Christchurch (Evening Post, 17 Dec. 1894). There has been much speculation about Arthur's apparent mental disability by recent critics, with Kirstine Moffat arguing that Arthur's handicap may have been a rumour 'perpetuated at a later date by Joseph as an excuse for financial difficulties' (2007). Trying to defend his financial irregularities in 1932, Joseph claimed that both Arthur and Edith were mentally unstable, and that the cost 
of their care had been a huge strain upon his income. These are claims that have not remained unchallenged: writing in The Book of New Zealand Women, published in 1991, Aorewa McLeod argued '[t]here is no evidence that his [Joseph's] claim is other than self-justification' (263). Similarly, Kirstine Moffat also rejected Joseph's allegations, stating that Edith's mental illness was a 'myth' started by her husband and 'perpetuated by several critics but [...] completely unfounded' (2007). Finally, with the Turnbull Library's acquisition of the Meikle papers, some light can be shed on the disputed issue of the mental capacities of mother and son. In point of fact, many letters in the collection by the Grossmanns' friends do refer to Edith's and Arthur's psychological problems. Writing about Arthur, Georgie Mackay recalled that he initially appeared to be a normal, healthy child, and that 'his abnormality did not show for the first few years' (Mackay to Meikle, 31 Jan. 1956) — an abnormality described by Marguerita Mulgan as 'arrested development' (Notes by Marguerita Mulgan). Edith herself was believed by friends to have first shown signs of mental instability as an adult, from around 1912 (Interview with Gray, 5 Nov. 1955). Mrs Pickmere, wife of Marguerita's brother, Arnold, with whom Edith lodged for a time in 1915, described Edith's intermittent paranoia and her 'fear of persecution, or people's intention[s]' (Interview with Mrs and Miss Pickmere, 9 Feb. 1956). Later, Miss Elle Blumhardt remembered that by 1916, 'Mrs Grossman [sic] was then already not right mentally [...] she shut her-self [sic] away from everybody because of her great fear of being persecuted. She suspected an enemy in everybody' (Blumhardt to Meikle, undated). Another friend also recalled that Edith believed 'people were following her and wanted to kill her and she had a habit of glaring at people who passed her as she imagined they would turn and follow her to kill her' (Unnamed Correspondent to Meikle, 6 Nov. 1955). Such recollections are important to those researching Edith Searle Grossmann's life: they are firsthand accounts of her neuroses and fears, and they offer some corroboration of Joseph's desperate excuses made to the University of Auckland Council in 1932 (though, of course, they do not excuse his criminality).

Crucially, the Meikle papers suggest that Edith's relationship with her son is the key to understanding the form, if not the core, of her psychological 
fracture. Sometime after 1914, Joseph took the decision to place Arthur on a farm in Christchurch where he was looked after by a friend of Edith's mother, Mrs Christian. Arthur was said to need a 'happy home atmosphere [...] [without] disturbance mentally as he became worse' (Unnamed Correspondent to Meikle, 6 Nov. 1955). The Christians provided him with this and he remained with them until at least 1956, when Mrs Christian's daughter confirmed to Georgie Mackay that he was still under her care (Mackay to Meikle, 31 Jan. 1956). However well intentioned this separation may have been, Arthur's removal had a definite impact upon his mother. Edith was said to have 'craved for her son to live with her' (Unnamed Correspondent to Meikle, 6 Nov. 1955) and incidents, reported by friends and acquaintances, which seem to show the deterioration of Edith's mental wellbeing, centred on her frequent attempts to have Arthur returned to her. For example, Miss Elle Blumhardt recalled how Edith had desperately implored her to bring Arthur back from Christchurch (Blumhardt to Meikle, undated). Others recalled how 'Mrs G[rossmann] could never understand why she could not have him [Arthur] to live with her' (Unnamed Correspondent to Meikle, 6 Nov. 1955). It appears that the separation of mother and son had a devastating effect upon Edith, from which her mind was never able to fully recover.

One should bear in mind, however, that whilst the Meikle papers provide a platform from which the orthodox view about Grossmann's mental state - offered by Moffat and McLeod - can be reviewed, the documents should not be taken completely at face value. Georgie Mackay, for instance, writes a letter largely sympathetic towards Joseph, and appears to be overly critical of Edith. ${ }^{9}$ She comments upon Edith's inability to manage a house and that she was 'quite unaware of the niceties of home decoration' (Mackay to Meikle, 31 Jan. 1956). Mackay correlates Edith's apparent slovenliness with her mental incapacities, thus opening the debate up to a feminist interrogation of the physical manifestations of psychological illness - in other words, does bad housekeeping really suggest mental deficiency? Such questioning points to the ambiguity of recollection and also the difficulty in offering a modern-day diagnosis of Grossmann's condition. Despite these reservations, however, the 
Meikle papers remain an important source of information when researching Grossmann's life.

Edith took Arthur to London in 1903, where she sought treatment for his disability. It is not yet known exactly where in London Edith and Arthur settled upon their arrival, though the Wellington Girls' High School Reporter of the second term in 1904 recorded that 'Mrs Grossmann is at present staying in West Kensington, London, where she is engaging in literary work of varied description' (17). Contemporary newspaper articles, located through the National Library of New Zealand's Papers Past database, provide more information about Grossmann's time in Europe, and are extremely useful in building up a picture of Grossmann's immersion in the cultural metropolis. It seems, however, that London, with all the attractions of literary circles and libraries, was initially only a base from which Arthur was sent for treatment and from where Edith left for the continent. Articles published in the Otago Witness indicate that she travelled extensively around Britain and Europe and did not spend long in one place. ${ }^{10}$ She wrote of her visits to Oxford, 'ancient and solemn' (8 Mar. 1905), Switzerland (4 Mar. 1908), travelling haphazardly by train through Italy (3 June 1908), and Greece, where she practised the language learnt in London. ${ }^{11}$ Grossmann also visited Edinburgh from where she wrote to her friend, the poet Jessie Mackay (Otago Witness, 3 May 1905), and holidayed in Wales (Otago Witness, 16 Nov. 1904).

Soon after her arrival in London, Grossmann became involved in the establishment of the Lyceum Club, an organisation founded by Constance Smedley that aimed to provide a meeting place for professional women. The Lyceum was located in Piccadilly, right in the heart of London's maledominated clubland (Woollacott, 111), and became one of the most prestigious and influential women's clubs of the early twentieth century. It functioned as a meeting place for suffragists, writers, and artists, and also inspired the formation of other Lyceum clubs in Europe, America, and the Dominions. Grossmann became involved in the organisation of the Club's Colonial Circle, joining the council of the Circle's New Zealand section (Evening Post, 2 Dec. 1908). She thus attended the Circle's inaugural dinner where she gave a lecture about the current status of New Zealand literature 
(Evening Post, 4 Aug. 1909). She acted as New Zealand's literary spokeswoman, encouraging those at the imperial centre to 'receive the embryo literature [of the Dominions] with their usual hospitality' (Evening Post, 4 Aug. 1909), in order to facilitate its growth and development. At these talks, Grossmann would give readings of poems and prose by New Zealand writers, including her friend Jessie Mackay, G. B. Lancaster and Blanche Baughan ${ }^{12}$ and, through her involvement with the Lyceum, was most likely responsible for bringing these artists to public attention in London.

Grossmann's political energy, however, was too wide-ranging to remain in the luxurious, cloistered confines of the Lyceum Club. In 1908 she published an article in the Westminster Review in which she referred to English women's struggle for suffrage, urging New Zealanders to support the movement:

The New Zealanders are not entitled to claim superiority over the English suffragists. If they showed more dignity they had not, on the other hand, the same self-sacrifice and heroism required of them (repr. Evening Post, 12 Aug. 1908).

Grossmann also became actively involved in the suffrage cause, marching along Waterloo Bridge in June 1910 with other members of the Lyceum Club, in a huge organised suffrage demonstration (Evening Post, 1 Aug. 1910). She seems to have thrown herself whole-heartedly into the hub and melee of London's cultural life, and may have found the climate creatively inspiring: $A$ Knight of the Holy Ghost (1907) and The Heart of the Bush (1910) were published whilst she lived there.

British passenger records show that Edith and Arthur returned to New Zealand on 28 November 1912. ${ }^{13}$ Arthur was removed to the Christchurch farm in 1914 and, from then on, his mother lived a peripatetic life, and may even have spent time in the psychiatric ward at Auckland's Avondale Hospital. ${ }^{14}$ Grossmann spent her last years living in Auckland at St Helier's Bay, again separated from her husband and son, where she was cared for by Ness Mackay. This last home seems to have been a final refuge; friends remembered how, after her return to New Zealand, Grossmann had sought out secluded, private places, presumably where she could write, or hide from 
the judgemental scrutiny of a society not equipped to cater for those living with mental illness. Some time before her death in 1931, a friend described visiting Grossmann at a cottage 'she had taken to live in, alone, at an isolated place somewhere down the harbour' (Unnamed Correspondent to Meikle, 6 Nov. 1955); similarly, Marguerita Mulgan 'remember[ed] her at one time living alone in a bach at a lonely part of Waikeke, wandering about half starved \& [sic] having to be brought to Auckland to be nursed again' (Notes by Marguerita Mulgan). It appears, then, that Grossmann was unable to care properly for herself towards the end and, although she craved isolation, needed the support of her friends.

It is also possible that Grossmann remained haunted by her son's absence and that this contributed to her inability to settle completely in the company of others. A copy of a letter held in the Meikle papers, written by Grossmann to the Auckland Star in 1929, just eighteen months before her death, points to her growing desperation with a society that allowed the separation of mentally-ill children from their families. She lamented the lack of a facility in the North Island to care for disabled young adults, meaning they are 'thrown upon the world just at the age when they need the most care' (Letter 8 Aug. 1929). Removing them to South Island institutions was not the answer, Grossmann argued, no doubt remembering her son's situation when writing that

\begin{abstract}
this would mean sending them away from all those who love them and to whom they still cling, and from all familiar faces and scenes. And these losses are far greater to the feebleminded than to the normal man or woman (Letter 8 Aug. 1929).
\end{abstract}

The letter reads as Grossmann's last reminder to society of the enforced, fragmented relationship between her and her son, and that Arthur's absence continued to weigh heavily upon her mind. She died on 27 February 1931 and was buried in Hillsborough cemetery, Auckland, on 1 March.

In 1894, when Grossmann was thirty, recently married and soon to become a mother, and the author of two novels, she published an article in the Otago Witness in which she mused upon the direction of New Zealand 
letters and the factors hindering the development of the colony's literature. Whilst the rich landscape 'must stimulate the imaginative and creative faculties', the realities of domestic life hindered its representation until 'all possibility of expression is lost and imagination itself is deadened ('Spare Half-Hours'). Grossmann wrote these words before her husband disrupted their family life by being sent to gaol, and before her son's mental difficulties became apparent. This was a time, then, when she could have expected her future to be bright - she may not have been a successful housewife, but she was a successful writer, and showed great promise. Yet the article in the Otago Witness foreshadows the obstacles that would later hinder Grossmann's literary output. By 1898, her world had been turned upside down and unexpected responsibilities became hers. Further, as the Meikle papers confirm, Grossmann was prone to psychological ill-health and was unable to sustain a lifestyle conducive to creativity. Thus her words of 1894 rang true:

There is something painful in the sight of these frustrated lives, where great gifts are at the best neglected or diverted into artificial talents; at the worst derided as eccentricities made a clog upon success, and a means of a man's alienation from the sympathies of his fellows ('Spare Half-Hours').

Yet Grossmann did leave a record of her ambitions for women in her four novels and countless articles. When these texts are considered alongside the recollections of her friends as provided to Phoebe Meikle, a fuller, more rounded picture of Edith Searle Grossmann emerges; a picture that proves inspirational and melancholy in turn.

[Author note]: I am grateful to Marsha Donaldson, archivist at the Alexander Turnbull Library, for bringing the Meikle papers to my attention, and to the Principal's Assistant at Christchurch Girls' High School for providing information about Grossmann's time there. 


\section{Notes}

${ }^{1}$ Moffat also provided a biographical sketch of Edith Searle Grossmann in an earlier edition of Kōtare: 'The Puritan Paradox: An Annotated Bibliography of Puritan and Anti-Puritan New Zealand Fiction, 1860-1940: Part 2: Reactions against Puritanism'. Kōtare 3.2 (2000). ${ }^{2}$ The Meikle Papers, held by the Alexander Turnbull Library (hereafter 'ATL'), are composed of several deposits relating to Grossmann's novels and her biography. The citations for the biographical papers are as follows: MS 2007-087-163, MS 2007-087-164, MS 2007-087-165, MS 2007-087-166, MS 2007-087-167, MS 2007-087-280, MS 2007-087-282, MS 2007-087285, MS 2007-087-311. See 'Works Cited' for specific details.

${ }^{3}$ As an indication of the esteem in which George Smales Searle was held, several newspapers carried notices of his death: Grey River Argus, 17 June 1885; North Otago Times, 18 June 1885; Hawera \& Normanby Star, 17 June 1885; Waikato Times, 18 June 1885; Taranaki Herald, 17 June 1885; Poverty Bay Herald, 17 June 1885;

Timaru Herald, 17 June 1885; Evening Post, 18 June 1885 (Papers Past Database).

${ }^{4}$ Date of birth taken from International Genealogical Index (online), where a Mary Ann Beeby is recorded as being born on 20 June 1823 at S[aint?] Gregory, London, daughter of William Beeby and Hannah Beeby. Information about Beeby's death obtained from Stanley Frame's 'Biographical Notes' and confirmed by Christchurch Cemetery Records (online).

${ }^{5}$ Constance's middle name, Clive, was a Searle family name.

${ }^{6}$ It is not known in which ship the family travelled, though there is a record of a Miss Edith Searle (age 11), Miss Constance Searle (age 8) and Mrs G S Searle (age 41) leaving Melbourne in March 1876 on the Arawata, and arriving in Bluff, New Zealand on 1 April 1876 (http://proarchives.imagineering.com.au/index search.asp?searchid=42 and http://www.yesteryears.co.nz/shipping/passlists/arawata.html). The ages are slightly out but no other records have been traced thus far.

${ }^{7}$ In her 'Chronology', Meikle noted that Grossmann received the Bowen Prize in 1881 for her essay 'The influence which the sea has exercised on the development of Eng. [sic] civilisation.' Meikle gave Grossmann's obituary by Professor Macmillan Brown (The Press, 7 Mar. 1931) as the source for this. However, contemporary newspapers, accessed through the Papers Past Database, record that a Joseph Burford (Poverty Bay Herald, 7 Mar. 1882) was the winner, not Edith. More intriguingly, a correction appeared in the Otago Witness on 11 Mar. 1882, in which it was stated that there had been an error with the winner's name: the actual winner in 1881, the paper said, was 'J. T. Grossmann' (presumably Edith's husband, Joseph).

${ }^{8}$ Chrissie Gray alleged that Joseph 'philandered' (Interview with Gray, 5 Nov. 1955). This was corroborated by a Miss Scott who knew the Grossmanns before Edith left for London in 1903: Meikle records how Miss Scott told her in April 1957 that she 'knows that he [Joseph] did have affairs with other women' (Interview with Miss Scott, Apr. 1957).

${ }^{9}$ One should also consider an allegation made by Chrissie Gray when reading Georgie's letter. Gray told Meikle that Georgie and Jessie Mackay's sister, Ness, who cared for Edith during her last years, had a relationship with Joseph and followed him to Sydney after he was sacked by the University of Auckland in 1932 (Interview with Chrissie Gray, 5 Nov. 1955). This may have influenced Georgie Mackay's opinion of Edith.

${ }^{10}$ The articles do not reveal if Arthur accompanied her.

${ }^{11}$ Otago Witness, 12 May 1909: 'I had been taking lessons in the language from a young Greek lady in London.' <http://paperspast.natlib.govt.nz>. Accessed 8 June 2008. Joseph Grossmann also told Dora Miller that Edith had 'taught herself modern Greek from ancient Greek' (Miller to Meikle, 6 Nov. 1955).

${ }_{12}$ Jessie Mackay (1864-1938), poet; G. B. Lancaster (1873-1945), pen-name of Edith

Lyttleton, novelist and short-story writer; Blanche Baughan (1870-1958), poet.

${ }^{13}$ Record from Find My Past website <http://findmypast.com>. Accessed 31 August 2008. Original document held in the National Archives, London.

${ }^{14}$ On 15 February 1956, Meikle seems to have accessed the Mental Hospital Records, for she notes that Edith was present in Avondale between 14 January 1920 and 8 March 1920. She was discharged in 5 January 1921 ('Notes on Edith Grossmann,' MS papers 2007-087281). Dora Miller's nameless friend also recalls visiting Edith at Avondale, but does not provide a date (Unnamed Correspondent to Meikle, 6 Nov. 1955). 


\section{Works Cited}

'An Interesting Personality'. Anonymous. Unknown newspaper. Copy provided by Searle family descendant.

'Births in the District of Beechworth in the Colony of Victoria, Schedule A, 1863'. Victoria Registry of Births, Deaths and Marriages, Historical Index Results. Department of Justice, Victoria, Australia. Accessed 27 May 2006. $<$ https://online.justice.vic.gov.au/bdm/home $>$

Blumhardt, Miss Elle. Letter to Phoebe Meikle. Undated. 'Correspondence relating to Edith Grossmann.' Alexander Turnbull Library. MS Papers 2007-087-164.

Blyth, Conrad. 'History of the Economics Department of the University of Auckland with some notes on the early academic teaching of economics in New Zealand.' Revised 28 Sep. 2006. Accessed 9 May 2008. <http://www.business.auckland.ac.nz/comwebContent/docs/C Blyth.pdf>

Christchurch City Council Cemeteries Database. Christchurch City Council. Accessed 31 Aug. 2008.

<http://librarydata.christchurch.org.nz/Cemeteries/interment>

Find My Past, online. Accessed 31 Aug. 2008. <http://findmypast.com>

Frame, Stanley G. Letter to Phoebe Meikle. 25 May 1956. 'Letters from Edith Grossmann's nephew, Stanley G. Frame'. Alexander Turnbull Library. MS Papers 2007-087-166.

_ 'Biographical notes on E S Grossmann and her parents.' Alexander Turnbull Library. MS Papers 2007-087-167.

Gray, Chrissie. Interview with Phoebe Meikle. 5 Nov. 1955. 'Notes on Edith Grossmann.' Alexander Turnbull Library. MS Papers 2007-087-285.

Grossmann, Edith Searle. In Revolt. London: Eden, Remington, 1893.

'Spare Half-Hours: Genius and Talent in the Colony'. Otago Witness 19 July 1894. Papers Past, online. Accessed 13 May 2008. <http://paperspast.natlib.govt.nz>

Hand Newton, C. T. Letter to Phoebe Meikle. 13 Feb. 1956. 'Correspondence relating to Edith Grossmann.' Alexander Turnbull Library. MS Papers 2007-087-164. February 1956.

Hankin, Cherry. 'Connon, Helen 1859/1860?-1903'. Dictionary of New Zealand Biography. Updated 22 June 2007. Accessed 22 Apr. 2008. <http://www.dnzb.govt.nz/dnzb/Find Quick.asp?PersonEssay=2C28>

Index to Outward Passengers to Interstate, UK, NZ and Foreign Ports 1852-1896. Public Record Office Victoria. Accessed 27 May 2006.

<http://proarchives.imagineering.com.au/index search.asp?searchid=42> 
In Memoriam, G S Searle. Otago: North Otago Times Office, Thames Street. Private document, supplied by Searle descendant.

International Genealogical Index, online. The Church of Jesus Christ of Latter-Day Saints. Accessed 27 Aug. 2008. <http://www.familysearch.org>

Letter 8 Aug. 1929. 'Papers relating to E. S. Grossmann.' Alexander Turnbull Library. MS Papers 2007-087-163.

Mackay, Georgina. Letter to Phoebe Meikle. 31 Jan. 1956. 'Correspondence relating to Edith Grossmann.' Alexander Turnbull Library. MS Papers 2007-087-164.

McLeod, Aorewa. 'Edith Searle Grossmann'. The Book of New Zealand Women. Eds. Charlotte MacDonald, Merimeri Penfold and Bridget Williams. Wellington: Bridget Williams Books, 1991. 263-67.

Meikle, Phoebe. 'Chronology of Life of Edith Grossmann.' Alexander Turnbull Library. MS Papers 2007-087-165

Miller, Dora L. Letter to Phoebe Meikle. 6 Nov. 1955. 'Correspondence relating to Edith Grossmann.' Alexander Turnbull Library. MS Papers 2007-087-164.

Moffat, Kirstine. 'The Puritan Paradox: An Annotated Bibliography of Puritan and Anti-Puritan New Zealand Fiction, 1860-1940: Part 2: Reactions against Puritanism', Kōtare 3.2 (2000). Accessed 20 Mar. $2009<$ http://www.nzetc.org/tm/scholarly/teiWhi032Kota.html>

'Edith Searle Grossmann, 1863-1931'. Kōtare 2007, Special Issue - Essays in New Zealand Literary Biography - Series One: 'Women Prose Writers to World War I'. Accessed 15 Apr. 2008. < http://www.nzetc.org/tm/scholarly/tei-Whi071Kota.html>

Mulgan, Alan. Interview with Phoebe Meikle. 17 Jan. 1956. 'Notes on Edith Grossmann.' Alexander Turnbull Library. MS Papers 2007-087-285.

Mulgan, Marguerita. Notes. Enclosed with letter by Alan Mulgan. 2 Feb. 1956. 'Correspondence relating to Edith Grossmann.' Alexander Turnbull Library. MS Papers 2007-087-164.

New Zealand Yesteryears. Accessed 27 May 2006. $<$ http://www.yesteryears.co.nz/shipping/passlists/arawata.html>

'Notes on Edith Grossmann.' Alexander Turnbull Library. MS Papers 2007-087-281.

Pickmere, Mrs and Miss. Interview with Mrs and Miss Pickmere. 9 Feb. 1956. 'Notes on Edith Grossmann.' Alexander Turnbull Library. MS Papers 2007-087-281.

Private Correspondence with Christchurch Girls' High School. Email from Principal's Personal Assistant. 29 Aug. 2006.

'Registry of Births, Deaths and Marriages'. Victoria Registry of Births, Deaths and Marriages, Historical Index Results. Department of Justice, Victoria, Australia. Accessed 27 May 2006. 
$<$ https://online.justice.vic.gov.au/servlet/IdxSearch?action=getHistldxPage\&queryIDP $\underline{\operatorname{aram}=590>}$

Roberts, Heather. 'Grossmann, Edith Searle 1863-1931'. Dictionary of New Zealand Biography. Updated 22 June 2007. Accessed 22 Apr. 2008.

<http://www.dnzb.govt.nz/dnzb/Find Quick.asp?PersonEssay=2G22>

Scott, Miss. Interview with Phoebe Meikle. 'Papers relating to E. S. Grossmann.' Alexander Turnbull Library. MS Papers ATL 2007-087-163.

Stafford, Jane and Mark Williams. Maoriland: New Zealand Literature 1872-1914. Wellington: Victoria University Press, 2006.

Unnamed Correspondent. Letter to Phoebe Meikle. 6 November 1955. Enclosed with letter by Dora Miller. 'Correspondence relating to Edith Grossmann.' Alexander Turnbull Library. MS Papers 2007-087-164.

Wellington Girls' High School. High School Reporter. Vol. 30. No. 36. Second Term, 1904.

Woollacott, Angela. To Try Her Fortune in London: Australian Women, Colonialism, and Modernity. New York: Oxford University Press, 2001. Accessed 29 May 2006. $<$ http://www.questia.com>

\section{$\underline{\text { Newspaper Articles }}$}

Papers Past Database. National Library of New Zealand. Accessed Apr. 2008 - Mar. 2009. <http://paperspast.natlib.govt.nz/cgi-bin/paperspast>

The following newspapers were accessed online using the Papers Past Database:

Otago Witness

Evening Post

Grey River Argus

North Otago Times

Hawera \& Normanby Star

Waikato Times

Taranaki Herald

Poverty Bay Herald

Timaru Herald 